\title{
7o- A Critical Approach to the Inclusion of the Revised Bloom's Taxonomy in Active Skills for Reading: Book 1
}

\section{Ömer Gökhan ULUM'}

APA: Ulum, Ö. G. (2021). A critical approach to the inclusion of the Revised Bloom's taxonomy in active skills for reading: Book 1. RumeliDE Dil ve Edebiyat Araştırmaları Dergisi, (25), 1130-1139. DOI: $10.29000 /$ rumelide.1037134.

\begin{abstract}
Bloom's Taxonomy was produced in 1956 by the educational psychologist Benjamin Bloom with the aim of fostering higher order thinking skills in education. In time, the original taxonomy was revisited by applying some changes. This up to date taxonomy mirrors a more active style of cognition and is possibly more precise. The revised one developed the practicality of the taxonomy by employing action words. There are six steps of cognitive domain in the revised version, the levels of which are conceptually different. These are remembering, understanding, applying, analyzing, evaluating, and creating in the revised version and they are beneficial in forming learning outcomes since specific verbs are particularly suitable for each level. Accordingly, this paper focuses on exploring how the revised Bloom's taxonomy is contained in the reading questions of an EFL reading course book. Therefore, two research questions were promoted to respond to the cognitive skills in the revised taxonomy. The first research question aims at evaluating the lower level while the second one hints on the higher cognition level. The analyzed EFL reading course book was inquired through descriptive content analysis method. The results of the study displayed that the assessed reading course book lacks the higher level cognitive skills underlined in the revised Bloom's taxonomy. Thus, related assumptions have been produced to suggest how the reading course books which are being produced or will be produced should refer to the revised Bloom's taxonomy while assessing reading comprehension.
\end{abstract}

Keywords: Cognitive domain, taxonomy, the revised Bloom's taxonomy, reading comprehension questions, assessing reading skills

\section{Yenilenmiş Bloom Taksonomisine İngilizce Aktif Okuma Becerileri Kitabında Ne Ölçüde Yer Verildiğine dair Eleştirel bir Yaklaşım}

$\ddot{\mathbf{O} z}$

Bloom taksonomisi 1956 yılında eğitim psikoloğu Benjamin Bloom tarafindan eğitimde üst düzey becerileri geliştirme amacıyla tasarlanmıştır. Zamanla orijinal taksonomi bazı değişikler uygulanarak yenilenmiştir. Güncel taksonomi daha etkin bilişsel becerileri yansıtır ve muhtemelen daha gelişmiştir. Yenilenmiş taksonomi fiil bildiren kelimeler kullanarak taksonominin pratikliğini artırmıştır. Yenilenmiş taksonomide seviyeleri kavramsal farklılıklar gösteren bilişsel alanda altı basamak vardır. Yenilenmiş taksonominin basamakları hatırlama, anlama, uygulama, analiz, değerlendirme ve yaratma basamaklarından oluşmaktadır. Yenilenmiş taksonominin her bir basamağı özel fiiller içerdiğinden taksonomi öğrenme kazanımları oluşturmada faydalıdır. $\mathrm{Bu}$ bağlamda, bu çalışma bir İngilizce okuma ders kitabında yer alan okuduğunu anlama sorularında

Doç. Dr., Mersin Üniversitesi, Eğitim Fakültesi, İngiliz Dili Eğitimi (Mersin, Türkiye), omergokhanulum@gmail.com, ORCID ID: 0000-0001-7685-6356 [Araştırma makalesi, Makale kayit tarihi: 30.08.2021-kabul tarihi: 20.12.2021; DOI: 10.29000/rumelide.1037134] 
yenilenmiş Bloom taksonomisine ne ölçüde yer verildiğini keşfetmeyi amaçlamaktadır. Bu yüzden, yenilenmiş taksonomide yer alan bilişsel becerileri irdeleyen iki araştırma sorusu geliştirilmiştir. Birinci araştırma sorusu alt seviye bilişsel becerileri irdelerken, ikinci araştırma sorusu üst düzey bilişsel becerileri irdelemektedir. Analiz edilen İngilizce okuma ders kitabı betimsel içerik analizi yöntemi ile irdelenmiştir. Araştırmanın sonuçları analiz edilen ders kitabının yenilenmiş Bloom taksonomisinde altı çizilen üst düzey bilişsel becerilerden yoksun olduğunu göstermiştir. Yazılmakta olan veya yazılacak olan okuma ders kitaplarının okuduğunu anlama sorularında yenilenmiş Bloom taksonomisine ne ölçüde yer vermeleri gerektiğine dair bu bağlamda ilgili önerilerde bulunulmuştur.

Anahtar kelimeler: Bilişsel alan, taksonomi, yenilenmiş Bloom taksonomisi, okuduğunu anlama soruları, okuma becerilerinin değerlendirilmesi

\section{Introduction}

In formal education, it is envisaged to provide students with the necessary knowledge, skills and attitudes for each grade level (McClune \& Jarman, 2010). While this is being done, it cannot be expected that the educational approaches that do not move the student into the center will be successful (Wright, 2011).Therefore, it is necessary to determine which knowledge, skills and behaviors will be gained by the student and at what level the student will be at the end of the learning process (Rodgers, 2008). This situation necessitates specifying and classifying the objectives according to learner characteristics and needs (Skrbic \& Burrows, 2014). Learning goals are the desired qualities that are acquired by the students through education (Marzano, 2010). The objectives desired to be acquired by the students have different levels and features (Adams, 2015). In the planning of instruction, the objectives are classified according to the desired level and characteristics (Baecher, Farnsworth, \& Ediger, 2014).According to Bloom, people are born with the mental equipment related to learning, and they have an unlimited learning capacity. However, their training process determines how much of their mental equipment and limits they can use (Rupani \& Bhutto, 2011). Therefore, when appropriate learning conditions are provided, children can learn almost anything that falls within their learning area (Coleman, 1968). The difference between children is not about their ability to learn more or less, but because of their individuality in their learning styles, interests, motivations and pace (Carbo, 1986; Oxford, 2003). In this context, taxonomy of educational goals is a framework of classification that expresses what students' learning goals or our expectations from them are as a consequence of instruction (Krathwohl, 2002).Taxonomy is the gradual classification of entities from simple to complex and each entity is a prerequisite for another (Forehand, 2010). In curriculum development, taxonomy is the ordering of the desired behaviors from simple to complex, from easy to difficult, from concrete to abstract, as prerequisites for each other (Ahmed et al., 2014). In this context, taxonomy is used to classify the learned behaviors that have a tight horizontal and vertical relationship among each other (Noble, 2004).In other words, in the learning-teaching process, taxonomy is used in determining the goals/behaviors that students will reach (Dopson \& Tas, 2004). Bloom's student Krathwohl (2002), together with his friends, revised Bloom's original classification. In the new classification, the cognitive domain was divided into two dimensions as content and process (Krathwohl \& Anderson, 2010). As in the original classification, the cognitive process dimensions in the revised one consist of six basic categories in a hierarchy from simple to complex (Pakpahan et al., 2021). Apart from this, some classifications that try to eliminate the deficiencies in the original Bloom's classification were developed as an alternative while the revised form is still based on the original classification (Newton, Da Silva, \& Peters, 2020). Behaviors that are desired to be acquired by individuals through education are determined by the gains in the curriculum. The level of these gains is determined by using taxonomies. Taxonomies in education are used for the 
classification of cognitive levels and they primarily focus on evaluation and achievements (Walbesser, 1963). The original taxonomy developed by Bloom et al. has a structure consisting of 6 steps, from simple to complex, from concrete to abstract, including knowledge, comprehension, application, analysis, synthesis and evaluation, and acquiring a behavior requires acquiring the previous behavior (Forehand, 2010). Krathwohl (2002) believed that Bloom's original taxonomy will provide a common language for the learning objectives to facilitate communication among educators. Further, it will be a basis for determining the specific meaning of the broad educational goals. He also believed that it would be used as a tool to determine the cohesion of the assessments. The changes in the curriculum and teaching methods and techniques, as well as the fact that the original taxonomy is based on the behaviorist approach, that the classification made in the cognitive field is one-dimensional, and that the acquisition of a behavior requires the acquisition of the previous behavior have emerged as the deficiencies of the original taxonomy (Tutkun, Güzel, Köroğlu, \& Ilhan, 2012). The revised Bloom's taxonomy consists of two dimensions, the knowledge dimension (Factual Knowledge, Conceptual Knowledge, Operational Knowledge and Metacognitive Knowledge) and the cognitive process dimension (Remembering, Understanding, Applying, Analyzing, Evaluating and Creating) (Amer, 2006). Further, the concepts of the original taxonomy changed from noun form to verb form. The knowledge dimension in the original taxonomy was changed to recall, the synthesis and evaluation steps were replaced, and the comprehension and synthesis steps were renamed as understanding and creating. The revised Bloom's taxonomy can be used in the analysis of the objectives of the curriculum in a clear, concise and visual way that it will help teachers not to confuse achievements with activities, and will also help them understand the relationships between learning-teaching activities and evaluation. It will also help them understand and adapt the teaching and material content of the curriculum accordingly. Bloom's taxonomy has been criticized over time and needed to be revised accordingly (Febrina, Usman, \& Muslem, 2019). Between 1995 and 2000, a study was conducted to reorganize and renew Bloom's taxonomy. Although a fundamental change was not brought to it, some important differences emerged (Ozola, 2014).The revised Bloom's taxonomy may also be grouped in three dimensions (Krathwohl, 2002).The first one refers to terminological change. In this dimension, the six levels in the original taxonomy were changed from noun to verb, and the lowest level of knowing was changed to remembering, while comprehension and synthesis were renamed. Secondly, a structural change was carried out. While Bloom's original taxonomy is one-dimensional, the developed taxonomy is twodimensional in terms of knowledge and cognition. The third change may be attributed to targets (Shell et al., 2010). The revised taxonomy involves more groups. These are the knowledge dimension and the cognitive process dimension. Knowledge types are found in the knowledge dimension. These are factual knowledge, conceptual knowledge, procedural knowledge and metacognitive knowledge (Airasian \& Miranda, 2002). Like the old version, the new taxonomy consists of six steps. However, it seems that the three digits (knowledge, comprehension and synthesis) have been renamed, the top two digits have been relocated, and the names of the digits have been transformed into verb form to match the way they are used in the targets (Bümen, 2007). Thus, this study focuses on discovering how the revised Bloom's taxonomy is involved in the reading comprehension questions of an EFL reading course book. 


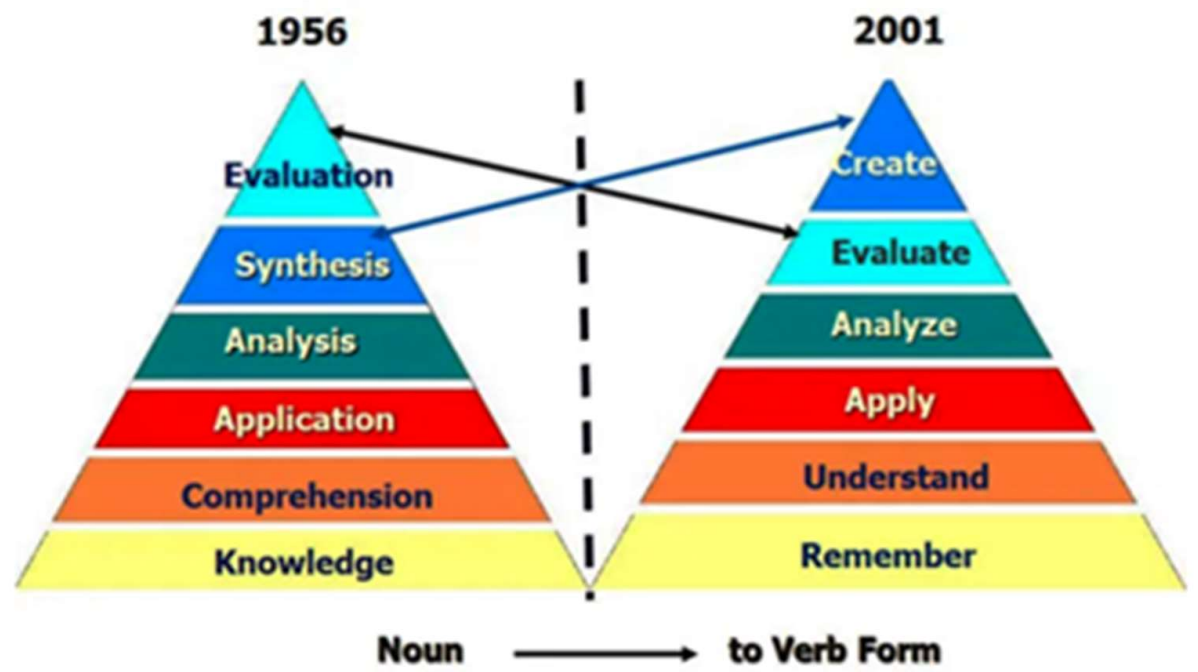

Figure 1.Bloom's Taxonomy Revised (Wilson, 2001)

\section{The research problem}

It is not easy for EFL/ESL teachers to produce their own reading materials to develop reading comprehension of the students and to evaluate the reading comprehension levels. Further, they do not have the necessary time and motivation to produce reading comprehension activities. Thus, they employ reading comprehension course books and they highly depend on these course books. The EFL reading course book that was chosen in this research paper is Active Skills for Reading: Book 1. The aim of this course book evaluation is to examine to what extent the reading course book includes higher and lower cognitive level questions suggested by the revised Bloom's taxonomy. The overall reading comprehension questions were assessed in the study. Consequently, this analysis will uncover whether or not the reading comprehension questions in the EFL course book refer to higher level thinking skills.

\section{Purpose of the study}

This study aims to examine the cognitive levels of the reading comprehension questions in the EFL reading course book titled Active Skills for Reading: Book 1. Thus, it clarifies whether or not there are any weaknesses or strengths of reading comprehension questions with respect to lower and higher order cognitive skills represented by the revised Bloom's taxonomy. Accordingly, the following research questions were put forward:

(1) To what extent do the reading comprehension questions in the EFL Reading course book Active Skills for Reading: Book 1include the lower order cognitive levels suggested by the revised Bloom's taxonomy?

(2) To what extent do the reading comprehension questions in the EFL Reading course book Active Skills for Reading: Book 1 include the higher order cognitive levels suggested by the revised Bloom's taxonomy? 


\section{Significance of the study}

This study analyses the reading comprehension questions in the EFL reading course book Active Skills for Reading: Book 1 and seeks to represent the intensity of lower and higher thinking levels involved in order to promote suggestions for the EFL reading teachers and course book authors preparing reading materials. The findings of this research paper will be of great significance for instructors when producing reading comprehension questions. The findings of the study will also increase the awareness of educational authorities, publishing companies, and education staff on the significance of the revised Bloom's taxonomy. Moreover, the findings of the study will be beneficial for instructors while evaluating reading course books which are designed by local and global stakeholders. Accordingly, they can choose the course books that much help them attain the curriculum goals.

\section{Limitations of the study}

EFL/ESL reading course books ought to include reading comprehension tasks demanding both low and high cognitive levels to contribute to students (Assaly \& Smadi, 2015). In this study, the revised Bloom's taxonomy has been solely employed to examine the reading comprehension questions. Thus, this research paper is limited only to the EFL reading course book Active Skills for Reading: Book 1. The collected data does not refer to the contents of other EFL reading course books. Further, this study only inquires the reading comprehension questions; thus, the results are limited to assessing EFL reading comprehension questions.

\section{Methodology}

The present study is based on a descriptive content analysis method which interprets the emergence of the categories of analysis. The extent of the revised Bloom's taxonomy in the reading comprehension questions was investigated accordingly. The textbook inquired in the paper is Active Skills for Reading: Book 1 which was authored by Neil J. Anderson and published by Thomson ELT Publishing. Initially, with the aim of finding solutions to the research problems (1) To what extent do the reading comprehension questions in the EFL Reading course book Active Skills for Reading: Book 1include the lower order cognitive levels suggested by the revised Bloom's taxonomy? (2) To what extent do the reading comprehension questions in the EFL Reading course book Active Skills for Reading: Book 1 include the higher order cognitive levels suggested by the revised Bloom's taxonomy?, question stems on every cognitive level and key words sampling the levels of the new taxonomy were employed to reach a conclusion. This research paper was based on a qualitative research design since it defined and evaluated the collected data. Related frequencies and percentages were illustrated in the study as the quantitative strand while samples from the reading questions were involved for the qualitative strand of the study. Question stems and words were utilized to find out the cognitive thinking levels. Descriptive content analysis was employed for the reading questions of each unit of the EFL reading course book while the related questions were collected, listed, and analyzed based on the revised Bloom's Taxonomy. Among many other models such as Vygotskian and Piagetian, the revised Bloom's Taxonomy may be recommended as a beneficial taxonomy to evaluate teaching and assessment materials (Zareian at al., 2015). Each coding category containing the samples of word stems for the levels of cognitive domains were provided and in order to make the data more manageable, the data were displayed in tables. In sum, the revised Bloom's Taxonomy was administered as the theoretical framework of this research paper and the findings were accordingly tabulated. 


\section{Data analysis and results}

The data of the study were interpreted through the descriptive content analysis (Vaismoradi, Turunen, \& Bondas, 2013) which contained classifying each question stem according to the six cognitive thinking levels stated in the taxonomy. The related percentages, frequencies, and example questions from the analyzed reading comprehension textbook representing the cognitive domains of the revised Bloom's taxonomy are displayed as follows. The results were given as both lower and higher cognitive thinking domains as well. The tables below and the related reports illuminate the mentioned facets.

Table 1.The Rate of the Cognitive Thinking Levels Stated in the Revised Bloom's Taxonomy in the Reading Questions

\begin{tabular}{lll}
\hline Level of question & f & \% \\
\hline Remember & 381 & 83.74 \\
Understand & 74 & 16.26 \\
Apply & - & - \\
Analyze & - & - \\
Evaluate & - & - \\
Create & - & - \\
Total & 455 & 100.00 \\
\hline
\end{tabular}

One can easily conceive from Table 1 that remembering level (83.74\%) emerged as the highest cognitive thinking level compared to the other levels. Moreover, understanding level follows the remembering level with a percentage of $\mathbf{1 6 . 2 6}$. However, no occurrence was detected in the other levels respectively. The pursuing examples refer to the reading questions appeared in the inquiry:

- What foods do you see in the picture? (remembering level, unit 1, p.11)

- Discuss. Why do some schools serve junk food to their students? (understanding level, unit 1, p.14)

Table 2.The Rate of the Higher and Lower Cognitive Domains of the Revised Bloom's Taxonomy in the Overall Reading Questions

\begin{tabular}{lll}
\hline Level of question & $\mathrm{f}$ & $\%$ \\
\hline Lower & 455 & 100.00 \\
Higher & - & - \\
Total & 455 & 100.00 \\
\hline
\end{tabular}

As it is simply perceived from the above table the lower cognitive thinking domain solely emerged (100.00). On the other hand, the higher cognitive thinking domain was detected with no emergence. 
Table 3.The Rate of the Remembering and Understanding Cognitive Levels of the Units

\begin{tabular}{lllll}
\hline & Remembering & \multicolumn{3}{c}{ Understanding } \\
Unit & $\mathrm{f}$ & $\%$ & $\mathrm{f}$ & $\%$ \\
\hline $\mathbf{1}$ & 19 & 67.86 & 9 & 32.14 \\
$\mathbf{2}$ & 31 & 91.18 & 3 & 8.82 \\
$\mathbf{3}$ & 39 & 84.78 & 7 & 15.22 \\
$\mathbf{4}$ & 31 & 93.94 & 2 & 6.06 \\
$\mathbf{5}$ & 28 & 87.50 & 4 & 12.50 \\
$\mathbf{6}$ & 45 & 93.75 & 3 & 6.25 \\
7 & 32 & 94.12 & 2 & 5.88 \\
$\mathbf{8}$ & 31 & 88.57 & 4 & 11.43 \\
$\mathbf{9}$ & 45 & 90.00 & 5 & 10.00 \\
$\mathbf{1 0}$ & 24 & 70.59 & 10 & 29.41 \\
$\mathbf{1 1}$ & 25 & 75.76 & 8 & 24.24 \\
$\mathbf{1 2}$ & 31 & 64.58 & 17 & 35.42 \\
\hline
\end{tabular}

One can be easily understood from the above table that the rate of remembering level is enormously more extensive compared to the rate of understanding level. Therefore, it is simply observed from Table 3 that the rates of remembering levels highly outnumber the rates of understanding levels in each unit, while no emergence was detected in the higher order cognitive domain.

\section{Discussion and conclusion}

In their study, Freahat and Smadi (2014) indicated that low order cognitive domain was dominant in the reading material of the university textbook and it does not display a higher level of thinking, just like the present study which represents similar results. Further, Freeman (2014) found out similar results in that the emergence of very basic, lower order questions rather than the ones that promote higher order thinking and linguistic skills was observed. In a similar vein, Riazi and Mosalanejad (2010) indicate that in all grades lower-order cognitive skills were more prevalent than higher order ones in the analyzed EFL textbooks. Moreover, Mizbani and Chalak (2017) revealed, in their study, that all of the activities of listening and speaking skills were grouped as the low level of cognitive complexity and could not lead the learners of this grade for high levels of learning objectives. Therefore, the related literature is full of studies assisting the present study in that the low order cognitive domain is more prevalent in course materials in general, and EFL course materials in particular, compared to the high order cognitive domain clarified by the revised Bloom's Taxonomy. Similarly, numerous studies, just like the present study, represent that course contents, curriculums, and materials lack the higher order cognitive skills suggested by the taxonomy of cognitive skills.

This study aimed to examine the reading questions of a course book, and the findings show that the questions hardly addressed higher cognitive skills and domains. The questions were related to remembering, understanding and applying. However, analyzing, evaluating and creating were hardly broached and addressed. This poses a serious problem for learners because they cannot approach language learning questions by evaluating and developing critical thinking skills (Nappi, 2017). Remembering is the first category in Bloom's taxonomy. Therefore, it is related to working memory and short term memory. In order to encode questions and their answers into long-term memory, higher 
cognitive skills should be triggered (Cowan, 2008). Unless these cognitive domains are activated, learning may not take place (Halpern, 1998). Therefore, English teachers should include additional questions so that they can be comprehended and reinforced by learners who learn a foreign and second language. Course books generally do not address higher cognitive domains. Therefore, practitioners should take Bloom's revised taxonomy into consideration in order to help learners acquire higher cognitive skills (Roohani, Taheri, \& Poorzangeneh, 2013).

Lower order cognitive skills are largely endorsed and reinforced in course books (Millrood \& Maksimova, 2018). However, what is important is that learners should be able to deal with higher order cognitive skills in order to develop their critical skills in language learning (Wall, 2015). Critical thinking skills can be developed through higher order cognitive domains (Miri, David, \& Uri, 2007; Ulum \& Taşkaya, 2019). Second and foreign language learners should be able to put various categories into a coherent manner. In addition, integrated skills of learners should be supported (MacVaugh, Jones, \& Auty, 2014). Some recommendations can be given:

- Teachers should incorporate higher order cognitive domains into reading questions.

- Critical thinking skills should be dealt with along with higher order cognitive skills.

- $\quad$ Long-term memory should be reinforced with additional questions.

- Language learners should be able to negotiate meaning in classroom settings where they should be given the opportunity to be involved in meaningful discussions.

- Course books should be developed in accordance with Bloom's revised taxonomy.

- Reading questions should be revised in line with higher order cognitive domains so that foreign language learners can reinforce their cognitive skills.

- Additional tasks and activities regarding higher order cognitive domains should be prepared by teachers.

- Alternative teaching techniques that endorse higher order cognitive domains should be tailored for learners' needs.

\section{References}

Adams, N. E. (2015). Bloom's taxonomy of cognitive learning objectives. Journal of the Medical Library Association: JMLA, 103(3), $15^{2}$.

Ahmed, N., Anwar, M. A., Wajahat, U., Edriss, A., \& Abdurahen, M. (2014). Bloom's taxonomy based proportionate curriculum development model. Journal of education and practice, 5(26), 12-17.

Airasian, P. W., \& Miranda, H. (2002).The role of assessment in the revised taxonomy.Theory into practice, 41(4), 249-254.

Amer, A. (2006). Reflections on Bloom's revised taxonomy. Electronic Journal of Research in Educational Psychology, 4(1), 213-230.

Assaly, I. R., \&Smadi, O. M. (2015).Using Bloom's Taxonomy to Evaluate the Cognitive Levels ofMaster Class Textbook's Questions. English Language Teaching, 8(5), 100-110.

Baecher, L., Farnsworth, T., \& Ediger, A. (2014).The challenges of planning language objectives in content-based ESL instruction. Language Teaching Research, 18(1), 118-136. 
Bümen, N. T. (2007). Effects of the original versus revised Bloom's Taxonomy on lesson planning skills: A Turkish study among pre-service teachers. International Review of Education, 53(4), 439-455.

Carbo, M. (1986).Teaching students to read through their individual learning styles. New Jersey: Prentice-Hall, Inc., Englewood Cliffs, NJ 07632.

Coleman, J. S. (1968). Equality of educational opportunity.Integrated Education, 6(5), 19-28.

Cowan, N. (2008). What are the differences between long-term, short-term, and working memory?.Progress in brain research, 169, 323-338.

Dopson, L. R., \&Tas, R. F. (2004). A practical approach to curriculum development: A case study. Journal of Hospitality \& Tourism Education, 16(1), 39-46.

Febrina, F., Usman, B., \& Muslem, A. (2019).Analysis of Reading Comprehension Questions by Using Revised Bloom's Taxonomy on Higher Order Thinking Skill (HOTS).English Education Journal, $10(1), 1-15$.

Forehand, M. (2010).Bloom's taxonomy. Emerging perspectives on learning, teaching, and technology, 41(4), 47-56. Retrieved on the $30^{\text {th }}$ of August, 2021 from https://www.d41.org/cms/lib/IL01904672/Centricity/Domain/422/BloomsTaxonomy.pdf

Freahat, N. M., \& Smadi, O. M. (2014). Lower-order and Higher-order Reading Questions in Secondary and University Level EFL Textbooks in Jordan. Theory \& Practice in Language Studies, 4(9).

Freeman, D. (2014). Reading comprehension questions: The distribution of different types in global EFL textbooks. In English Language Teaching Textbooks (pp. 72-110). Palgrave Macmillan, London.

Halpern, D. F. (1998).Teaching critical thinking for transfer across domains: Disposition, skills, structure training, and metacognitive monitoring. American psychologist, 53(4), 449.

Krathwohl, D. R. (2002). A revision of Bloom's taxonomy: An overview. Theory into practice, 41(4), 212-218.

Krathwohl, D. R., \& Anderson, L. W. (2010). Merlin C. Wittrock and the revision of Bloom's taxonomy. Educational psychologist, 45(1), 64-65.

MacVaugh, J., Jones, A., \&Auty, S. (2014). Implicit, stand-alone or integrated skills education for undergraduates: a longitudinal analysis of programme outcomes. Journal of Further and Higher Education, 38(6), 755-772.

Marzano, R. J. (2010). Designing \& teaching learning goals \& objectives. Bloomington: Solution Tree Press.

McClune, B., \&Jarman, R. (2010). Critical Reading of Science-Based News Reports: Establishing a knowledge, skills and attitudes framework. International Journal of Science Education, 32(6), 727-752.

Millrood, R., \&Maksimova, I. (2018). Cognitive skills in education: typology and development. Языки культура, 42, 137-147.

Miri, B., David, B. C., \& Uri, Z. (2007).Purposely teaching for the promotion of higher-order thinking skills: A case of critical thinking. Research in science education, 37(4), 353-369.

Mizbani, M., \& Chalak, A. (2017). Analyzing listening and speaking activities of Iranian EFL textbook

Prospect 3 through Bloom's Revised Taxonomy. Advances in Language and Literary Studies, 8(3), 3843.

Nappi, J. S. (2017). The importance of questioning in developing critical thinking skills. Delta Kappa Gamma Bulletin, 84(1), 30.

Newton, P. M., Da Silva, A., \& Peters, L. G. (2020, July).A pragmatic master list of action verbs for bloom's taxonomy. In Frontiers in Education, 5, 107. 
Noble, T. (2004).Integrating the Revised Bloom. Teachers college record, 106(1), 193-211.

Ozola, S. (2014).Views on taxonomy and learning. Education in a changing society, 1, 152-159.

Oxford, R. L. (2003). Language learning styles and strategies: Concepts and relationships. International review of applied linguistics in language teaching, 41(4), 271-278.

Pakpahan, S. F., Pakpahan, S., Purba, I. D. S., \& Nasution, J. (2021). Analysis Reading Comprehension Questions by Using Revised Bloom's Taxonomy on Higher Order Thinking Skill (HOTS). IDEAS: Journal on English Language Teaching and Learning, Linguistics and Literature, 9(1), 259 271.

Riazi, A. M., \& Mosalanejad, N. (2010). Evaluation of Learning Objectives in Iranian High-School and

Pre-University English Textbooks Using Bloom's Taxonomy. TESL-EJ, 13(4).

Rodgers, T. (2008).Student engagement in the e-learning process and the impact on their grades. International Journal of Cyber Society and Education, 1(2), 143-156.

Roohani, A., Taheri, F., \&Poorzangeneh, M. (2013).Evaluating Four Corners textbooks in terms of cognitive processes using Bloom's revised taxonomy. Journal of Research in Applied Linguistics, 4(2), 51-67.

Rupani, C. M., \& Bhutto, M. I. (2011). Evaluation of existing teaching learning process on Bloom's Taxonomy. International Journal of Academic Research in Business and Social Sciences, 1, 119128.

Shell, D. F., Brooks, D. W., Trainin, G., Wilson, K. M., Kauffman, D. F., \& Herr, L. M.(2010).Theunified learning model. In The Unified Learning Model (pp. 1-4).Dordrecht: Springer.

Skrbic, N., \& Burrows, J. (2014).Specifying learning objectives. Learning, teaching and development: Strategies for action, London: Sage, 39-69.

Tutkun, O. F., Güzel, G., Köroğlu, M., \&Ilhan, H. (2012). Bloom's revised taxonomy and critics on it. The Online Journal of Counselling and Education, 1(3), 23-30.

Ulum, H., \&Taşkaya, S. M. (2019).Evaluation of the Activities in the Turkish Coursebooks(Student's Books and Workbooks) Used at the 2nd, 3rd, And 4th Classes of State Primary Schools According to Revised Bloom's Taxonomy. Kastamonu Education Journal, 27(1), 107-118.

Walbesser, H. H. (1963). Curriculum evaluation by means of behavioral objectives. Journal of Research in Science Teaching, 1(4), 296-301.

Wall, T. F. (2015).The transferability of higher order cognitive skills. Procedia-Social and Behavioral Sciences, 174, 233-238.

Wilson, L. O. (2001). Bloom's Taxonomy Revised. Retrieved on the $24^{\text {th }}$ of June, 2021 from https://thesecondprinciple.com/essential-teaching-skills/blooms-taxonomy-revised/

Wright, G. B. (2011). Student-centered learning in higher education. International Journal of Teaching and Learning in Higher Education, 23(1), 92-97.

Vaismoradi, M., Turunen, H., \& Bondas, T. (2013). Content analysis and thematic analysis: Implications for conducting a qualitative descriptive study. Nursing \& health sciences, 15(3), 398-405.

Zareian, G., Davoudi, M., Heshmatifar, Z., \&Rahimi, J. (2015).An evaluation of questions in two ESP coursebooks based on Bloom's new taxonomy of cognitive learning domain. International Journal of Education and Research, 3(8), 313-326. 